\title{
Morphological and immunohistochemical findings in upper gastrointestinal biopsies of patients with Crohn's disease of the ileum and colon
}

\author{
JP VAN SPREEUWEL, ${ }^{*}$ J LINDEMAN, $₫$ AM VAN DER WAL, $\dagger$ I WETERMAN, \\ J KREUNING, $\ddagger$ CJLM MEIJER $† \S$
}

From the *Department of Internal Medicine, Division of Gastroenterology, St Antonius Hospital, Utrecht, and the Departments of $\nmid$ Pathology and $\ddagger$ Gastroenterology, University Medical Center, Leiden, The Netherlands, and the §Department of Pathology, Stichting Samenwerking Delftse Ziekenhuizen, Delft

SUMMARY The histological findings and the number of immunoglobulin-containing cells in gastric and duodenal biopsies from patients with Crohn's disease of the large or small bowel, or both, with and without upper gastrointestinal complaints, are reported and compared with those of healthy controls and patients with chronic non-specific gastritis and duodenitis. The gastric and duodenal biopsies from patients with Crohn's disease showed a higher incidence of chronic non-specific inflammation and a significant increase of IgM-containing cells compared with healthy controls. The increase of IgM-containing cells in the lamina propria cannot be explained by the high incidence of chronic non-specific inflammation, a condition shown to have increased numbers of IgM-containing cells as well, since patients with Crohn's disease of the ileum or colon, or both, without histological abnormalities of the gastric and duodenal mucosa also showed an increase of IgM-containing cells. It is concluded that both the high incidence of chronic nonspecific inflammation in gastric and duodenal biopsies and the increased number of IgMcontaining cells are an expression of Crohn's disease as a systemic disorder of the gastrointestinal tract.

Crohn's disease is a focal, chronic often granulomatous inflammatory condition of the gastrointestinal tract that may affect any part of it but has a preference for the small and large bowel. Besides typical epithelioid cell granulomas the bowel wall shows transmural, often focal, mononuclear infiltrates consisting of lymphocytes, histiocytes and plasma cells. Recent histological and immunopathological studies suggest that Crohn's disease is a generalised disorder of the gastrointestinal tract. Thus Sommers and Korelitz ${ }^{1}$ found histological abnormalities in gastric and duodenal biopsies in 19 of 45 patients with Crohn's disease of ileum and colon without radiological evidence of disease in the upper gastrointestinal tract. Twelve lesions localised in the gastric antrum or duodenal bulb were considered suggestive of Crohn's disease. Basu $e t a l^{2}$ found non-specific focal lymphocytic infiltrates in the macroscopically normal oral mucosa in $67 \%$ of patients with Crohn's disease of the ileum and colon.

Accepted for publication 28 January 1982
Earlier studies of immunoglobulin (Ig)-containing cells have yielded conflicting results, probably due to difficulties in measurement of Ig-containing cells by immunofluorescence. However, recent studies of Ig-containing cells in affected parts of the bowel wall of patients with Crohn's disease have shown an increase in number of Ig-containing cells, especially IgG and IgM-containing cells. ${ }^{34}$ One of these studies also showed an increase in the number of IgM-containing cells in parts of the bowel wall not apparently involved by Crohn's disease. These findings suggest that Crohn's disease is a generalised disorder of the entire gastrointestinal tract with preference sites in ileum and colon.

In the present study we have investigated both histologically and immunohistochemically gastric and duodenal biopsies of patients with Crohn's disease of the ileum and colon with and without upper gastrointestinal complaints. We have compared the histological and immunohistochemical findings in these biopsies with those of patients with gastritis and duodenitis and of 10 healthy volunteers. The results showed that patients with Crohn's disease of 
the ileum and colon without upper gastrointestinal complaints have a higher incidence of histological abnormalities in their gastric and duodenal biopsies and a higher number of IgM-containing cells in the lamina propria of the stomach and the duodenum than healthy volunteers.

These findings are interpreted as evidence for the assumption that Crohn's disease is a generalised disorder of the gastrointestinal tract.

\section{Patients}

Three groups of individuals were examined.

(i) Twenty-two patients, 10 men, 12 women, with Crohn's disease of the ileum, colon, or both. Their mean age was $37 \mathrm{yr}$ (range 20-68 yr). The diagnosis was based on clinical, radiological and histological criteria. $^{5-8}$ Sixteen patients were subjected to a bowel resection: (ileocaecal resection 12 patients; colectomy 3 patients; jejunectomy 1 patient). All the specimens examined showed in the mucosa disproportionate inflammation and basal cryptitis either granulomatous or with an infiltrate of histiocytes and eosinophilic granulocytes. Moreover all the specimens had aphtous or fissure-like ulcerations extending onto or into the muscularis propria, transmural fibrosis and transmural lymphocyte infiltrations. Multinucleated giant cells were found in two patients and epithelioid cell granulomata in seven patients. In two patients the histological diagnosis was based on colonic biopsies showing basal histiocytic cryptitis and epithelioid cell granulomata. In four patients the diagnosis was based on clinical and radiological criteria. These patients showed a typical ileitis terminalis radiologically. Colonic biopsies in these patients showed focal lymphohistiocytic infiltrates and basal histiocytic cryptitis but epithelioid cell granulomata were not found. At the time of biopsy Crohn's disease was either active or quiescent. Ten patients received sulphasalazine or corticosteroids, or both, and 12 received no medical treatment. Five patients suffered from non-ulcer dyspepsia, the others had no upper gastrointestinal complaints.

(ii) Ten healthy volunteers (nine men, one woman) without abdominal complaints served as controls. Their mean age was 31 yr (range 20-54 yr). Informed consent was obtained. All volunteers had normal gastric and duodenal mucosa as judged by the criteria of Kreuning et al. ${ }^{9}$

(iii) Ten patients (eight men, two women), mean age $42 \mathrm{yr}$ (range 23-62 yr), with chronic nonspecific duodenitis, gastritis, or both, served as controls. The diagnosis was based on the histological criteria described by Whitehead ${ }^{6}$ and Kreuning. ${ }^{9}$ The histological findings in the biopsies of these patients are listed in Table 1.

\section{Material and methods}

Upper gastrointestinal endoscopy was performed using a fibreoptic endoscope. Twelve biopsies were taken from standard sites, five from the duodenum and seven from the stomach as described by Kreuning. The biopsy specimens were extended on a gauze with the luminal site up and fixed for four hours in a sublimate-formaline mixture for optimal demonstration of Ig-containing cells. ${ }^{10-12}$

Next tissue samples were embedded in paraplast, cut in sections ( $4 \mu \mathrm{m}$ thick) perpendicular to the luminal surface and mounted on glass slides. Sections were stained with haematoxylin and eosin, and periodic acid-Schiff. Biopsies taken from the duodenal bulb, from the gastric antrum and from the gastric fundus were stained specifically for $\operatorname{IgA}, \operatorname{IgM}$, IgG and IgE heavy chains, using an indirect immunoperoxidase technique. ${ }^{10}$ Appropriate controls were done according to Sternberger ${ }^{13}$ and Rosekrans et al ${ }^{14}$ Rabbit antisera against IgA, IgM and IgG heavy chains were purchased from Dakopatts (Denmark). The rabbit antisera against IgE heavy chains were purchased from the Central Laboratory of the Netherlands Red Cross Blood Transfusion Service, Amsterdam. The specificity

Table 1 Histological findings in patients with chronic non-specific duodenitis or gastritis, or both

\begin{tabular}{|c|c|c|}
\hline Duodenum & Gastric antrum & Gastric fundus \\
\hline $\begin{array}{l}1 \text { chron duodenitis } \\
2 \text { chron duodenitis } \\
3 \text { normal } \\
4 \text { chron duodenitis } \\
5 \text { act chron duodenitis } \\
6 \text { chron duodenitis } \\
7 \text { act chron duodenitis } \\
8 \text { foc act chron duodenitis } \\
9 \text { chron duodenitis } \\
10 \text { chron duodenitis }\end{array}$ & $\begin{array}{l}\text { chron gastritis }+ \text { atrophy } \\
\text { act chron gastritis } \\
\text { act chron gastritis + atrophy } \\
\text { chron gastritis + atrophy } \\
\text { act chron gastritis + atrophy } \\
\text { chron gastritis + atrophy } \\
\text { normal } \\
\text { foc act chron gastritis + atrophy } \\
\text { foc act chron gastritis + atrophy } \\
\text { normal }\end{array}$ & $\begin{array}{l}\text { chron superf gastritis } \\
\text { normal } \\
\text { chron superf gastritis } \\
\text { normal } \\
\text { chron gastritis + atrophy } \\
\text { normal } \\
\text { normal } \\
\text { normal } \\
\text { chron gastritis + atrophy } \\
\text { normal }\end{array}$ \\
\hline
\end{tabular}

chron $=$ chronic, act $=$ active, foc $=$ focal, superf $=$ superficial. 
of the antisera was confirmed by immunoelectrophoresis, immunofluorescence and immunoperoxidase stainings on bone marrow preparations monoclonal for IgA, IgM or IgG heavy chains and their respective $\kappa$ or $\lambda$ light chains. The IgE antiserum showed no reaction with the monoclonal bone marrow preparations and was checked for tissue performance using sections from a tonsil of an atopic patient. These tonsils are known to contain increased numbers of IgE-containing cells. Horseradish peroxidase-labelled goat antirabbit IgG was obtained from Miles (Yedah, Israel). The IgA-, IgM-, IgG-, and IgE-stained sections were used for morphometrical analysis. Immunoperoxidasestained sections were photographed on transparencies with a standard magnification $(100,8 \times)$ and projected on a graphic tablet interfaced to a computer (Ibas I, Kontron, München). The lamina propria area was limited by two lines perpendicular to the muscularis mucosa and this area was measured per mm muscularis mucosa length. Every transparency contained approximately one millimetre of muscularis mucosa. The number of Ig-containing cells was counted in approximately the same area in three consecutive sections and expressed per $0.1 \mathrm{~mm}^{2}$ lamina propria and per $0.5 \mathrm{~mm}$ muscularis mucosa. The latter is comparable with the "mucosal tissue unit" constituting a $6 \mu \mathrm{m}$ thick and $0.5 \mathrm{~mm}$ wide block of tissue including the mucosa at full height from the muscularis mucosa described by Brandtzaeg and Baklien. ${ }^{15}$ Biopsies from the gastric fundus as a rule contained no or insufficient muscularis mucosa. In these tissue sections the number of Igcontaining cells was expressed per $0.1 \mathrm{~mm}^{2}$ lamina propria of the foveolar layer and per $0.1 \mathrm{~mm}^{2}$ glandular layer. Statistical analysis was performed according to the Wilcoxon rank test; $p<0.05$ was adopted as a level of significance.

\section{Results}

The histological findings in gastric and duodenal biopsies of patients with Crohn's disease of the ileum, colon, or both, are listed in Table 2. As shown chronic non-specific inflammation-that is, gastritis and duodenitis was encountered frequently in the biopsies of patients with Crohn's disease in contrast to the biopsies of healthy volunteers in which no histological abnormalities were found. Sometimes chronic non-specific inflammation followed a focal pattern; an example is given in Fig. 1. No granulomas were found. In healthy controls the number of Ig-containing cells was lowest in the fundus of the stomach, the vast majority of cells being present in the foveolar layer with only a sporadic cell in the glandular layer. In the antrum Ig-containing cells were more frequent whereas the highest number was found in the duodenal bulb (Tables 3 and 4). As in other parts of the intestine, IgA-containing cells predominated; IgM-containing cells came second in frequency; IgG-containing cells were less frequent, and no IgE-containing cells were found except for a sporadic cell in an antral biopsy in a patient with Crohn's disease. A significant increase

Table 2 Histological findings in gastric and duodenal biopsies from 22 patients with Crohn's disease of the ileum, colon, or both

\begin{tabular}{|c|c|c|}
\hline \multicolumn{3}{|l|}{ Duodenum } \\
\hline Normal & $(1)^{*}$ & $13 / 22$ \\
\hline Chron non-specific duodenitis & & $1 / 22$ \\
\hline Act chron non-specific duodenitis & $(2)^{*}$ & $4 / 22$ \\
\hline Foc act chron non-specific duodenitis & $(1)^{*}$ & $3 / 22$ \\
\hline Inflammation-scar & $(1)^{*}$ & $1 / 22$ \\
\hline \multicolumn{3}{|l|}{ Antrum } \\
\hline Normal & $(3)^{*}$ & $10 / 22$ \\
\hline Foc chron non-specific gastritis & & $1 / 22$ \\
\hline Act chron non-specific gastritis & $(1)^{*}$ & $1 / 22$ \\
\hline Foc act chron non-specific gastritis & $(1)^{*}$ & $4 / 22$ \\
\hline Chron non-specific gastritis with atropl & & $2 / 22$ \\
\hline Act chron non-specific gastritis with at & & $2 / 22$ \\
\hline Foc act chron non-specific gastritis witl & & $2 / 22$ \\
\hline \multicolumn{3}{|l|}{ Corpus } \\
\hline Normal & $(4)^{*}$ & $15 / 22$ \\
\hline Chron non-specific gastritis & & $1 / 22$ \\
\hline Foc chron non-specific gastritis & & $1 / 22$ \\
\hline Foc act chron non-specific gastritis & $(1)^{*}$ & $1 / 22$ \\
\hline Chron non-specific gastritis with atrop & & $1 / 22$ \\
\hline Foc act chron non-specific gastritis wit & & $2 / 22$ \\
\hline Total atrophic chron non-specific gastr & asia & $1 / 22$ \\
\hline
\end{tabular}

${ }^{*}$ Number of patients with upper gastrointestinal complaints.

Ten healthy volunteers showed no histological abnormalities.

chron $=$ chronic, act $=$ active, foc $=$ focal. 

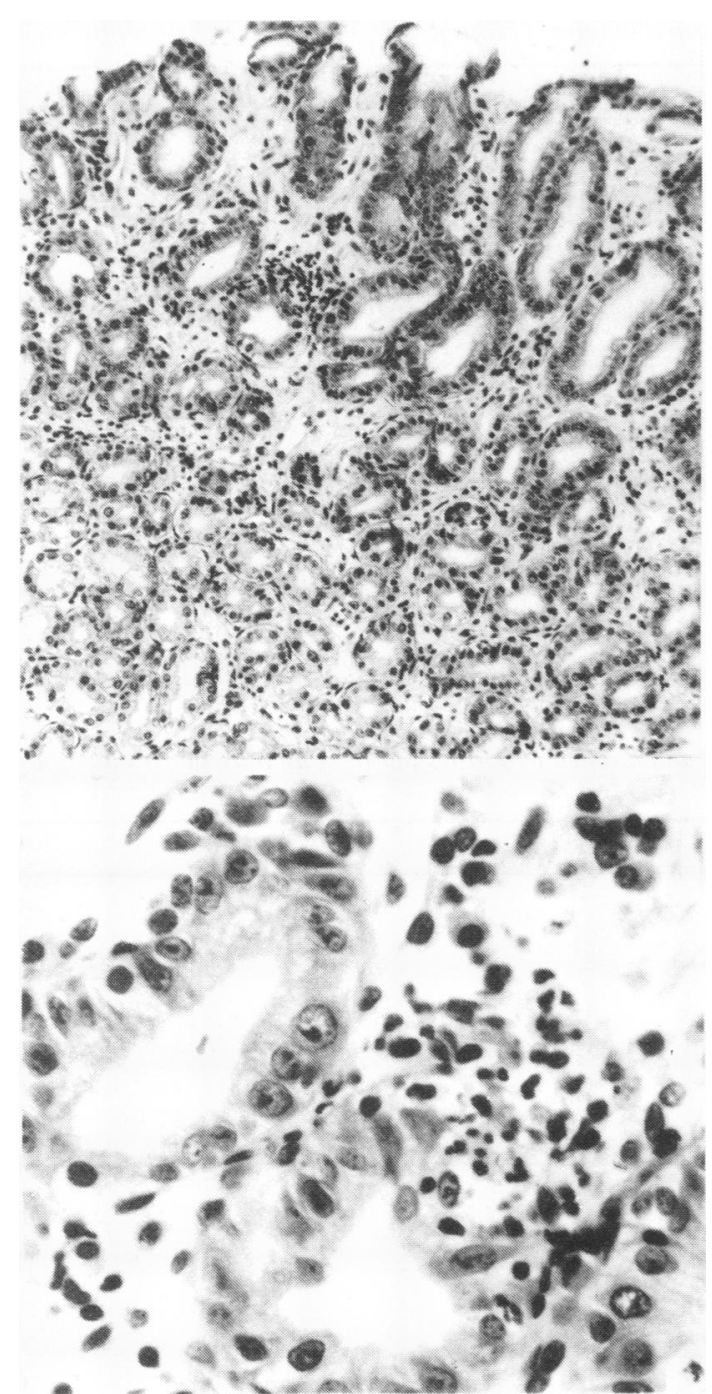

Fig. 1 (Above) Biopsy from gastric fundus of a patient with Crohn's disease showing focal non-specific inflammation. Haematoxylin and eosin $\times 40$. (below) detail of the above infiltrate $\times 125$.

of IgM-containing cells was found in the duodenal bulb (Fig. 2), the antrum and foveolar layer of the fundus of the stomach in biopsies of patients with Crohn's disease as compared to healthy controls. Both the number of IgM-containing cells per 0.5 mm muscularis mucosa (Table 4) and per $0.1 \mathrm{~mm}^{2}$ lamina propria area (Table 3 ) differed significantly. The number of IgG-containing cells was increased but due to a large variation between individuals, these results were not always significant (Tables 3 and 4). Plasma cells form an important constituent

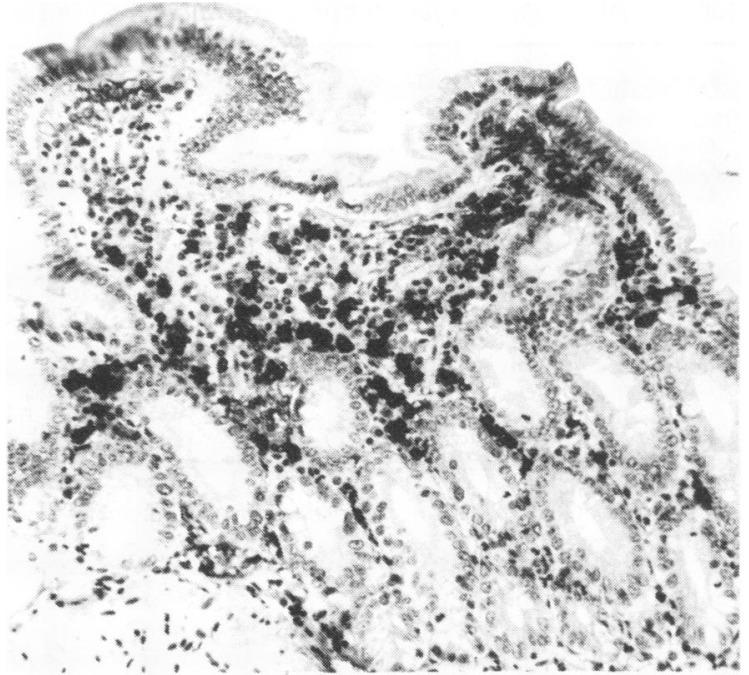

Fig. 2 Histologically normal biopsy from the duodenal bulb of a patient with Crohn's disease showing a high number of IgM-containing cells. Immunoperoxidase $\times 100$.

of the inflammatory infiltrate in chronic non-specific gastritis and duodenitis. This is reflected by the high number of Ig-containing cells in biopsies from patients with gastritis and duodenitis. The increase of Ig-containing cells in these patients is caused mainly by IgA-containing cells and to a lesser extent by IgM- and IgG-containing cells (Tables 3 and 4). Since gastritis and duodenitis were frequently found in patients with Crohn's disease we compared biopsies from patients with Crohn's disease without histological abnormalities with biopsies from healthy volunteers (Tables 5 and 6). As shown patients with Crohn's disease without histological abnormalities had a significantly higher number of IgM-containing cells compared to healthy controls. The number of IgA-containing cells in biopsies from the duodenal bulb did not differ significantly resulting in a higher IgM:IgA ratio.

However, the number of IgA-containing cells in gastric biopsies from patients with Crohn's disease without histological abnormalities of the gastric mucosa was increased when compared to healthy volunteers. No significant differences in IgMcontaining cells were found between patients with Crohn's disease and chronic non-specific inflammation and patients with gastritis and duodenitis though biopsies of patients with Crohn's disease showed a tendency towards higher relative numbers of IgM-containing cells. The number of IgGcontaining cells showed a marked variation. In biopsies without histological abnormalities the number of IgG-containing cells was low and differed only 
Table 3 Mean absolute number of Ig-containing cells in gastric and duodenal biopsies per $0.1 \mathrm{~mm}^{2}$ lamina propria area

\begin{tabular}{|c|c|c|c|}
\hline & $\operatorname{Ig} A$ & $\operatorname{Ig} M$ & $\operatorname{Ig} G$ \\
\hline \multicolumn{4}{|l|}{ Healthy volunteers $(n=10)$} \\
\hline Duodenal bulb & $185 \pm 90$ & $22 \pm 13$ & $5 \pm 9$ \\
\hline Gastric antrum & $25 \pm 14$ & $1 \pm 1$ & $1 \pm 1$ \\
\hline Foveolar layer of gastric fundus & $17 \pm 20$ & $1 \pm 1$ & $1 \pm 1$ \\
\hline \multicolumn{4}{|l|}{ Morbüs Crohn $(n=22)$} \\
\hline Duodenal bulb & $167 \pm 52(\mathrm{NS})$ & $54 \pm 30(p=0 \cdot 004)$ & $23 \pm 20(p=0.01)$ \\
\hline Gastric antrum & $87 \pm 56(p=0.003)$ & $16 \pm 18(\mathrm{p}=0.002)$ & $12 \pm 20(p=0.003)$ \\
\hline Foveolar layer of gastric fundus & $72 \pm 39(p=0.005)$ & $15 \pm 15(\mathrm{p}=0.002)$ & $4 \pm 6(\mathrm{NS})$ \\
\hline \multicolumn{4}{|l|}{ Duodenitis/gastritis $(n=10)$} \\
\hline Duodenal bulb & $283 \pm 124(\mathrm{NS})$ & $48 \pm 33(\mathrm{NS})$ & $8 \pm 14(N S)$ \\
\hline Gastric antrum & $149 \pm 87(p=0.002)$ & $16 \pm 13(p=0 \cdot 002)$ & $24 \pm 30(p=0.005)$ \\
\hline Foveolar layer of gastric fundus & $154 \pm 125(p=0.009)$ & $19 \pm 23(\mathrm{p}=0.014)$ & $22 \pm 38(\mathrm{p}=0.03)$ \\
\hline
\end{tabular}

NS = not significant.

$\mathrm{p}$ values indicate levels of significance versus healthy volunteers.

Table 4 Mean absolute number of Ig-containing cells in gastric and duodenal biopsies per $0.5 \mathrm{~mm}$ muscularis mucosae ("mucosal tissue unit")

\begin{tabular}{|c|c|c|c|}
\hline & $\operatorname{Ig} A$ & $\lg M$ & $I g G$ \\
\hline $\begin{array}{c}\text { Healthy volunteers } \\
\text { Duodenal bulb } \\
\text { Gastric antrum }\end{array}$ & $\begin{array}{r}127 \pm 48 \\
14 \pm 13\end{array}$ & $\begin{array}{r}17 \pm 5 \\
1 \pm 1\end{array}$ & $\begin{array}{l}4 \pm 7 \\
1 \pm 1\end{array}$ \\
\hline $\begin{array}{c}\text { Morbus Crohn ( } n \\
\text { Duodenal bulb } \\
\text { Gastric antrum }\end{array}$ & $\begin{aligned} 133 & \pm 69(\mathrm{NS}) \\
83 & \pm 79(p=0.01)\end{aligned}$ & $\begin{array}{l}42 \pm 26(p=0.008) \\
12 \pm 12(p=0.01)\end{array}$ & $\begin{array}{l}20 \pm 18(p=0.02) \\
17 \pm 35(p=0.02)\end{array}$ \\
\hline $\begin{array}{c}\text { Gastritis/duodenitis } \\
\text { Duodenal bulb } \\
\text { Gastric antrum }\end{array}$ & $\begin{array}{l}330 \pm 227(p=0.02) \\
186 \pm 152(p=0.01)\end{array}$ & $\begin{array}{l}51 \pm 30(p=0.03) \\
18 \pm 17(N S)\end{array}$ & $\begin{array}{l}11 \pm 14(\mathrm{NS}) \\
33 \pm 49(\mathrm{p}=0.02)\end{array}$ \\
\hline
\end{tabular}

NS = not significant

p values indicate levels of significance versus healthy volunteers.

Table 5 Mean absolute number of Ig-containing cells in gastric and duodenal biopsies per $0 \cdot 1 \mathrm{~mm}^{2}$ lamina propria area

\begin{tabular}{|c|c|c|c|}
\hline & $\operatorname{Ig} A$ & $\operatorname{Ig} M$ & $I g G$ \\
\hline $\begin{array}{l}\text { Healthy volunteers }(n=10) \\
\text { Duodenal bulb } \\
\text { Gastric antrum } \\
\text { Foveolar layer of gastric fundus }\end{array}$ & $\begin{array}{r}185 \pm 90 \\
25 \pm 14 \\
17 \pm 20\end{array}$ & $\begin{aligned} 22 & \pm .13 \\
1 & \pm 1 \\
1 & \pm 1\end{aligned}$ & $\begin{array}{l}5 \pm 9 \\
1 \pm 1 \\
1 \pm 1\end{array}$ \\
\hline $\begin{array}{l}\text { Morbus Crohn without histological abnormalities } \\
\text { Duodenal bulb }(n=13) \\
\text { Gastric antrum }(n=10) \\
\text { Foveolar layer of gastric fundus }(n=15)\end{array}$ & $\begin{aligned} 143 & \pm 30(\mathrm{NS}) \\
69 & \pm 54(\mathrm{NS}) \\
68 & \pm 44(\mathrm{p}=0 \cdot 02)\end{aligned}$ & $\begin{array}{l}48 \pm 29(p=0.049) \\
11 \pm 15(p=0.002) \\
10 \pm 9(p=0.02)\end{array}$ & $\begin{aligned} 10 & \pm 9(\mathrm{NS}) \\
4 & \pm 3(\mathrm{p}=0.02) \\
2 & \pm 3(\mathrm{NS})\end{aligned}$ \\
\hline $\begin{array}{l}\text { Morbus Crohn with histological abnormalities } \\
\text { Duodenal bulb }(n=9) \\
\text { Gastric antrum }(n=12) \\
\text { Foveolar layer of gastric fundus }(n=7)\end{array}$ & $\begin{aligned} 189 & \pm 61(\mathrm{NS}) \\
104 & \pm 54(\mathrm{p}=0 \cdot 009) \\
84 & \pm 15(\mathrm{p}=0.02)\end{aligned}$ & $\begin{array}{l}59 \pm 31(\mathrm{p}=0.003) \\
20 \pm 20(\mathrm{p}=0.0003) \\
25 \pm 21(\mathrm{p}=0.004)\end{array}$ & $\begin{array}{c}33 \pm 22(p=0.005) \\
19 \pm 25(p=0.006) \\
8 \pm 8(p=0.03)\end{array}$ \\
\hline
\end{tabular}


Table 6 Mean absolute number of Ig-containing cells in gastric and duodenal biopsies per 0.5 mm muscularis mucosae ("mucosal tissue unit")

\begin{tabular}{|c|c|c|c|}
\hline & $\operatorname{Ig} A$ & $\operatorname{Ig} M$ & $\lg G$ \\
\hline $\begin{array}{l}\text { Healthy volunteers }(n=10) \\
\text { Duodenal bulb } \\
\text { Gastric antrum }\end{array}$ & $\begin{array}{r}127 \pm 48 \\
14 \pm 13\end{array}$ & $\begin{aligned} 17 & \pm 5 \\
1 & \pm 1\end{aligned}$ & $\begin{array}{l}4 \pm 7 \\
1 \pm 1\end{array}$ \\
\hline $\begin{array}{l}\text { Morbus Crohn without histol } \\
\text { Duodenal bulb }(n=13) \\
\text { Gastric antrum }(n=10)\end{array}$ & $\begin{array}{r}121 \pm 42 \text { (NS) } \\
53 \pm 39 \text { (NS) }\end{array}$ & $\begin{aligned} 37 & \pm 21(p=0) \cdot(1) 3) \\
7 & \pm 9(p=0 \cdot(04)\end{aligned}$ & $\begin{array}{l}8 \pm 8(N S) \\
4 \pm 4(p=0 \cdot(1) 3)\end{array}$ \\
\hline $\begin{array}{l}\text { Morbus Crohn with histologi } \\
\text { Duodenal bulb }(n=9) \\
\text { Gastric antrum }(n=12)\end{array}$ & $\begin{array}{l}144 \pm 88(N S) \\
118 \pm 99(p=0.01)\end{array}$ & $\begin{array}{l}46 \pm 31(\mathrm{p}=0 \cdot(1) 2) \\
16 \pm 13(\mathrm{p}=0 \cdot(12)\end{array}$ & $\begin{aligned} 29 & \pm 18(\mathrm{p}=0 \cdot(004) \\
30 & \pm 47(\mathrm{p}=0 \cdot(04)\end{aligned}$ \\
\hline
\end{tabular}

NS $=$ not significant .

$\mathrm{p}$ values indicate levels of significance versus healthy volunteers.

significantly from healthy controls for the gastric antrum (Tables 5 and 6). However, a strongly increased number of IgG-containing cells was found in biopsies from patients with Crohn's disease showing duodenitis, gastritis, or both (Tables 5 and 6).

\section{Discussion}

This study shows that patients with Crohn's disease of the ileum, colon, or both, with and without upper gastrointestinal complaints have a higher incidence of chronic non-specific inflammation and a higher number of IgM-containing cells in their gastric and duodenal mucosa as compared to healthy volunteers. The increased number of IgM-containing cells was not due to the increased incidence of chronic non-specific gastritis and duodenitis, conditions shown to have increased numbers of $\operatorname{IgA}$ and IgM containing cells, since patients with Crohn's disease and histologically normal gastric and duodenal mucosa also showed increased numbers of IgMcontaining cells.

Moreover when in the gastric and duodenal biopsies histological abnormalities were found, also an increase in the number of IgG-containing cells was observed.

All these immunohistochemical findings agree with the observations of Brandtzaeg and Baklien ${ }^{3}$ and Rosekrans et $\mathrm{al}^{4}$ in colonic biopsies. These authors found increased numbers of IgG and IgM containing cells in bowel specimens affected by Crohn's disease. Rosekrans et al $^{4}$ also found increased numbers of IgM-containing cells in quiescent parts of the colon in patients with Crohn's disease. These and our data indicate that patients with Crohn's disease have an increased number of IgM-containing cells in the mucosa throughout the gastrointestinal tract. The significance of this is uncertain and needs further study. Whether the IgM antibodies produced by these cells are specific for a single, so far unidentified, antigen or whether they are directed against multiple antigens is of special interest. In the latter case this may reflect a functionally deficient $\operatorname{IgA}$ barrier since it is supposed ${ }^{16}$ that $\operatorname{IgA}$ - and IgM-containing plasma cells form a first line of defence as far as local humoral immunity is concerned and it is well recognised that IgM-containing cells are increased in IgA deficiency. The same authors suggest that IgG-containing cells form a second line of defence and this may explain the increase of IgG-containing cells in gastric and duodenal biopsies from patients with Crohn's disease showing chronic non-specific inflammation as has been shown for patients with Crohn's disease of the colon as well. ${ }^{34}$

Lymphohistiocytic infiltrates-that is, focal chronic non-specific inflammation in the intestinal mucosa have been described as an important histological feature in bowel segments affected by Crohn's disease. ${ }^{17}$ It has even been suggested that these lesions precede the granulomas so characteristic for Crohn's disease. ${ }^{18}$ Basu et $a l^{2}$ found nonspecific lymphocytic infiltrates in the macroscopically normal oral mucosa in $67 \%$ of patients with Crohn's disease of the ileum and colon. These findings point to a relation between focal nonspecific lymphohistiocytic infiltrates in mucosal biopsies and Crohn's disease. In conclusion we believe that both the focal lymphohistiocytic infiltrates and the increased numbers of IgMcontainıng cells in gastric and duodenal biopsies from patients with Crohn's disease of the ileum, colon, or both, are an expression of Crohn's disease as a generalised disorder of the gastrointestinal tract.

The authors wish to thank Dr PHJ Kurver for his advice on morphometrical equipment and statistical analysis, and Ms RJJR Scholte and Mrs GC Soeters for typing the manuscript. 


\section{References}

' Sommers SC, Korelitz BI. Duodenal cell counts and histopathology in Crohn's disease. In: Pen̂a AS, Weterman IT, Booth CC, Strober W, eds. Recent advances in Crohn's disease. The Hague: Martinus Nijhoff, 1981;47-51.

${ }^{2}$ Basu MK, Chesner IM, Thomson RR, Asquith P. Significance of lip biopsies in the diagnosis of Crohn's disease (routine histology and immunofluorescence) In: Pena AS, Weterman IT, Booth CC, Strober W, eds. Recent advances in Crohn's disease. The Hague: Martinus Nijhoff, 1981;43-6.

${ }^{3}$ Brandtzaeg P, Baklien K. Immunopathology of the intestinal lesion in Crohn's disease. $Z$ Gastroenterol 1979;17 (suppl):77-82.

${ }^{4}$ Rosekrans PCM, Meijer CJLM, van der Wal AM, Cornelisse CJ, Lindeman J. Immunoglobulin-cont aining cells in inflammatory bowel disease of the colon. A morphometric and immunohistochemical study. Gut 1980;21:941-7.

${ }^{5}$ Korelitz BI, Present DH, Alpert LI, Marshak RH, Janowitz HD. Recurrent regional ileitis after ileostomy and colectomy for granulomatous colitis. N Engl J Med 1972;287:110-4.

- Whitehead R. Mucosal biopsy of the gastrointestinal tract. London: Saunders, 1973.

${ }^{7}$ Morson BC. Technique and interpretation of rectal biopsies in inflammatory bowel disease, pp. 209-230. In: Sommers SC. ed. Pathology annual. New York: Appleton-Century-Crofts, 1974.

${ }^{8}$ Meijer CJLM, Bosman FT, Lindeman J. Evidence for predominant involvement of the B-cell system in the inflammatory process in Crohn's disease. Scand $J$ Gastroenterol 1979;14:21-32.

- Kreuning J, Bosman FT, Kuipers S, van der Wal AM, Lindeman J. Gastric and duodenal mucosa in healthy individuals. An endoscopic and histopathological study of 50 volunteers.J Clin Pathol 1978;31:69-77.

${ }^{10}$ Bosman FT, Lindeman J, Kuipers G, van der Wal AM, Kreuning $J$. The influence of fixation on immunoreactivity of plasma- cells in routinely processed intestinal biopsy specimens. Histochemistry 1977;53:57-62.

"Piris JN, Thoman ND. A quantitative study of the influence of fixation on immunoperoxidase staining of rectal mucosal plasma cells. J Clin Pathol 1980;33:361-4.

${ }^{12}$ Heyworth MF. Influence of two different fixatives on the identification of plasmacells in human rectal mucosa. $J$ Histochem Cytochem 1980;28:1018-20.

${ }^{13}$ Sternberger L. Immunohistochemistry. Englewood Cliffs: Prentice Hall, 1979.

${ }^{14}$ Rosekrans PCM, Meijer CJLM. Cornelisse CJ, van der Wal AM, Lindeman J. Use of morphometry and immunohistochemistry of small intestinal biopsies in the diagnosis of food allergy. $J$ Clin Paihol 1980;33: 125-30.

is Brandtzaeg P, Baklien K, Fausa O, Hoel PS. Immunohistochemical characterisation of local immunoglobulin formation in ulcerative colitis. Gastroenterology 1974;66:1123-36.

${ }^{16}$ Brandtzaeg P, Baklien K. Immunohistochemical studies of the formation and epithelial transport of immunoglobulins in normal and diseased human intestinal mucosa. Scand $J$ Gastroenterol 1976;11, suppl 36:1-45.

17 Yardley JH, Hamilton SR. Focal non-specific inflammation (FNI) in Crohn's disease. In: Penta AS, Weterman IT, Booth $\mathrm{CC}$, Strober W, ed. Recent advances in Crohn's disease. The Hague: Martinus Nijhoff, 1981;62-6.

${ }^{18}$ Schmitz-Moormann P. Becker $\mathrm{H}$. Histological studies of the formal pathogenesis of the epithelioid cell granuloma in Crohn's disease In: Pen̂a AS, Weterman IT, Booth CC, Strober W, ed. Recent advances in Crohn's disease. The Hague: Martinus Nijhoff, 1981;76-9.

Requests for reprints to: Dr JP van Spreeuwel, Depart ment of Internal Medicine, Division of Gastroenterology St Antonius Hospital, Jan van Scorelstraat 2, Utrecht, The Netherlands. 